\title{
Introducing Design Thinking to High School Art Education
}

\author{
Chenxuan Meng ${ }^{1 *}$ \\ ${ }^{1}$ University of Toronto, John H. Daniels Faculty of Architecture, Landscape, and Design \\ *Corresponding author. Email: chenxuan.meng@mail.utoronto.ca
}

\begin{abstract}
Design thinking is currently considered a different way of satisfying customers' requirements for diverse products or services, which has incorporated multi-disciplinary and multi-dimensional logical thinking into design objects. In the contemporary society, various design fields are emphasizing the significance of design thinking, such as industrial design, architectural design, landscape design, graphic design, and clothing design. As creativity becomes more and more valued and appreciated, design thinking is no longer limited to higher education. However, when managing to embed this kind of thinking into high school education, educators still face diverse difficulties and challenges. As a result, this article provides a critical approach to comprehensively analyzing and examining those published articles related to design thinking, acknowledging both of its merits and limitations as an art teaching approach in high school.
\end{abstract}

Keywords: design thinking, high school art education, innovation, creativity.

\section{INTRODUCTION}

Design thinking is one of the topics that have been extensively discussed in the past ten years. Its role is no longer limited to the design industry but extends to management, consultancy, medicine, and other fields. At the same time, as a multidimensional and non-linear way of thinking, design awareness is also an important strategy for interdisciplinary exploration. [1]

In recent years, as the significance of creativity has attracted the public's attention, educators have conducted extensive research on incorporating design thinking into the field of art education. Also, many countries have been involved in this movement and manage to provide guidance for the seamless integration. In England and Wales, design courses have become regular courses for about 30 years, which gradually demonstrates its benefits and essences for calculation and literacy. [2] Similarly, in Norway, the government considers design and architecture as an indispensable part of their national art curriculum, thus offering numerous opportunities for students to participate in some of its artistic decisions. [3] As design thinking becomes popular, diverse research tools have emerged including Stanford's model which is commonly utilized to present a workflow for creative thinking. Subsequently, a number of educators used this approach as a foundation and attempted to incorporate critical design thinking into high school art teaching.
Accordingly, this paper aims to not only synthesize research on design education and design thinking but also delve into the problems arising from integrating design thinking into high school art education. The research questions are as follows:

1) Why is it important to introduce design thinking into current high school art education?

2) What are the characteristics of the impact of design thinking on art education?

3) What are the challenges of embedding design thinking into high school art education?

\section{DESIGN THINKING}

\subsection{Definition of design thinking}

Rowe's book, Design Thinking [4], was essential in bringing design thinking to the public's consciousness. Initially, the discussion is still limited within the field of design where design thinking is considered as a cognitive tool that functions in the entire design process reflecting designer abilities and enhancing design practice and education.[5] Then in 2008, Brown extends the notions of design and claimed that design thinking can be seen as a discipline that takes users' requirements into account. Businesses can benefit from this way of thinking to create additional value and opportunity.[6] Roger Martin also 
suggested that design thinking can be incorporated in business school management courses. [7] This is largely due to the fact that designers often solve challenging problems in restrictive projects; therefore, they can foster inductive logical thinking and gain a thorough knowledge of the client's requirements at the same time, thereby providing the most appropriate solutions through cooperation. Accordingly, the application of design thinking can also encourages people from all walks of life to use their imagination and actively solve problems.[8]

\subsection{Design thinking models}

In the beginning, design thinking was strongly associated with the design industry, so it's better to think of it as a casual way of thinking rather than being restricted to a standard model. By attracting and bringing in experts and scholars from other fields, design thinking is no longer limited in the design industry and is gradually creating diverse helpful development models, among which Stanford's model is the most well-known and frequently used in curriculum design.

Stanford's design thinking model consists of five stages, including empathize, define, ideate, prototype, and test which is iterative. Participants will go through the procedure multiple times in order to come up with a superior solution.

Empathizing is the first step toward creating a peoplecentered design which means that any design project should prioritize the consideration of the customer's sentiments and requirements. During this process, participants communicate and interact with clients in order to gain insight into their thoughts and motivations. Also, it enables participants to develop empathy and learn to think from different perspectives. In the second stage, participants define and construct problems based on the results of previous research, including users' requirements, contextual factors, and other real-world variables. In the following steps, participants brainstormed a list of possible solutions and answers. When engaging in the brainstorming process, it is crucially essential to postpone the important decision in order to draw creative inspiration. In addition, creating a prototype becomes the central part of the process. Finally, the prototype should be thoroughly examined and tested, which concentrates on keeping interacting with customers, gaining customers' feedback, then iteratively repeating the previous stages, and modifying as needed. This process should be repeated until a reasonable solution is found within a limited timeframe.[9]

\section{REASONS AND FEASIBILITY OF INTRODUCING DESIGN THINKING INTO HIGH SCHOOL ART EDUCATION}

\section{1. background of the current art education}

In the current high school education where students acquire the knowledge through repetition and seas of the exams, most schools still consider students' scores in the college entrance examination as the benchmark for their academic abilities. In the context of this exam-oriented education, the distorted concept of further education also affects the vast majority of parents and students as they are inclined to believe that high school education is primarily designed to prepare for the college entrance examination and other lucrative purposes. This standardized test can only measure a limited part of students' abilities and skills [10] and may demotivate students and cause them to lose innovative thinking after entering the university. Under this circumstance where the excessive emphasis is placed on mastering the fundamental knowledge and skills, students' creativity and imagination will not be able to obtain substantial enhancement, or even not be properly developed. At the same time, their overall literacy competence may also be hampered, which is detrimental for them to become mature and flexible knowledge recipients in the future. [11]

In contemporary society, schools should play an effective role in cultivating students' personalities, sense of responsibility, and so on. In this situation, the schools should create and employ the relevant courses and training to further develop students' ability to deal with complex problems and actively receive multiple information; thereby enhancing their imagination and creativity at the same time. More importantly, the aforementioned skills and abilities are in significant demand in various fields including science, business, and social organizations in the 21 st century. [12]

At this stage, high school art education is mainly composed of music and art with an emphasis on students' aesthetic and artistic appreciation. Due to the low level of time and energy that students need to devote to such courses, the impact exerted on the students' attention and participation are low and restricted. Under the current curriculum reform, there are still some potential problems in art education. Among them, teachers have established high authority in class so students are not equipped with appropriate and sufficient discourse power and the sense of participation, thereby demotivating students in art learning. In addition, the majority of art education curriculum still lacks innovative instructional concepts and reasonable course arrangements. [13] Accordingly, the characteristics and workflow of design thinking can remove the shortcomings of contemporary art education to a certain extent, and thus provide opportunities and soil for cultivating students' creativity. 


\subsection{The characteristics of design thinking in art education}

\subsubsection{Empathize}

Empathy plays a crucial role in the enhancement of students' creativity and innovation, according to Lim.[14] The involvement is both practically and emotionally meaningful for students as they design products to fulfill their requirements and promote mental strength. In addition, a project on interactive design thinking organized by Leila Aflatoony, Ron Wakkary, and Carman Neustaedter [15] found that students paid more attention to communicating and interacting with people in the later stages of the project than in the beginning, thus displaying greater empathy.

\subsubsection{Creative confidence and positive learning attitude}

Brainstorming is one of the key steps of developing design thinking in which process students are allowed to exchange their insights and stand on an equal footing. The decision post-tone is also a feature of this stage.[8] Also, postponing the decision can also be regarded as a significant feature [8] that enables those seemingly absurd proposals to be considered thoroughly and comprehensively. Students who can express their opinions have developed a stronger sense of creative confidence and enthusiasm; at the same time, their participation will be significantly improved. Compared with the traditional art education where teachers function as the role of an authoritative expert, the current design education provides harmonious, equal, and positive teacher-student relationships so the learning experiences can be promoted for all stakeholders. [16]

\subsubsection{Cooperative skills}

There are generally two ways to collaborate in design thinking courses. [7] By cooperating with the users, students can gain a more penetrating understanding of users' cognition and requirements. Moreover, peer cooperation entails students working cooperatively and benefiting mutually from one another which is different from the individually-finished assignment form in the traditional art class. For example, students were able to collaborate more effectively as a consequence of the interactive design thinking project led by Leila Aflatoony and her colleagues. [15] Similarly, Katherine, who used the Stanford model to design an interdisciplinary STEAM project for her students, also found this results in a significant improvement in students' teamwork ability which will exert a profound effect on their future study and job opportunities.

\subsubsection{Multidisciplinary}

Projects based on design thinking are often a combination of multiple disciplines, allowing for the employment of interdisciplinary approaches. [17] Students can utilize those cutting-edge software technologies in various fields to better express their artistic perceptions. In this case, students' homework is no longer a single picture or musical composition, but a multi-dimensional, multi-disciplinary combination of artistic outputs.

\subsection{Challenges and opportunities}

1: When confronted with multiple related pieces of knowledge, students may be inclined to feel distracted and fragmented. [8]

2: The knowledge reserves of high school students are still relatively limited [8] and also a limited amount of time will be left to supplement their academic knowledge due to severe schooling pressure. Therefore, when they first encounter this completely new form of the design task, they may become struggled and anxious to advance the tasks that require knowledge from multiple fields, thereby resulting in a failure.

3: As previously mentioned, high school students can merely afford the insufficient time for art education. For the whole project, it might be regarded as timeconsuming to take the iterative five steps of the Stanford model and find the best solution through repeated testing.

4: One of the projects mentioned in this article, the interactive design project, was carried out smoothly because of the guidance of experts.[15] Many high schools, particularly those in remote rural areas may not have such resources so professional expertise should be made available and pervasive.

5: Art educators are concerned that creative thinking courses will completely and entirely replace art education. [18] In a world where art is nothing more than a tool used only for industry and employment, students will not see art itself as valuable.

Students in high schools acquire and nurture these artistic perceptions to stimulate their intellectual growth and aesthetic appreciation. Eisner noted that art is a way of communicating without using language and this can also be counted as one of its main benefits. [19] By engaging in art education, people are able to discover intrinsic value and express their personal emotions at the same time. Nevertheless, numerous art educators oppose the use of art to benefit and serve the industry so the role of design thinking in art education has yet to be determined. Also, according to Andrew who endeavored to emphasize design thinking in art education[18], students were not aware of the essence of this thinking 
when considering whether art can be utilized to solve problems. Consequently, this type of research still currently lacks sufficient evidence to support it.

\section{CONCLUSION}

From the perspective of some parents and schools, design thinking may be a waste of time in its early stages because such competencies can neither be directly presented on students' official transcripts nor will they rapidly demonstrate students' academic achievement. However, in the long run, using design thinking to direct students' arts education in high school enables them to develop multiple abilities. Confidence, innovation, empathy, cooperation, and more importantly, the multidimensional thinking patterns are merely a few examples of ability ratios. Although there are still many obstacles and challenges to solve in bringing design thinking into high school art education, this does not come to the conclusion that design should completely replace art. As a way to assist students in broadening their thought, design thinking should be embedded in a certain stage of high school art education and collaborative art projects should be created which differs from traditional assignment requirements for students' individual endeavors. There are still concerns to be answered concerning the proportion of curriculum arrangement and specific course design throughout the high school.

\section{REFERENCES}

[1] N. Anderson, Design thinking: Employing an effective multidisciplinary pedagogical framework to foster creativity and innovation in rural and remote education, Aust. Int. J. Rural Educ., vol. 22, no. 2, pp. 42-52, 2012.

[2] R. Green and J. Steers, Design education - Now you see it; Now you don't, The Design and Technology Association and The National Society for Education in Art and Design, 2006. [Online]. Available: https://www.nsead.org/publications/researchreports-and-reviews/research-reports-andpresentations/design-education-now-you-see-itnow-you-dont/.

[3] Eurydice National Unit, European Commission, Arts and cultural education at school in Europe: Norway, 2007 . [Online]. Available: http://mediatheque.citemusique.fr/mediacomposite/ cim/_Pdf/10_40_Norway_EN.pdf.

[4] P. Rowe, Design Thinking. Cambridge, Mass: MIT Press, 1998.

[5] N. Cross and K. Dorst, Research in Design Thinking. Delft: Delft University Press, 1992.

[6] T. Brown, Design thinking, Harvard Bus. Rev., vol. 86, no. 6, pp. 1-10, 2008.
[7] D. Dunne and R. Martin, Design thinking and how it will change management education: An interview and discussion, Acad. Manage. Learn. Educ., vol. 5, no. 4, pp. 512-523, 2006. DOI: https://doi.org/10.5465/amle.2006.23473212.

[8] M. Carroll, S. Goldman, L. Britos, J. Koh, A. Royalty and M. Hornstein, Destination, imagination and the fires within: Design thinking in a middle school classroom, Int. J. Art Des. Educ., vol. 29, no. 1, pp. 37-53, 2010. DOI: https://doi.org/10.1111/j.1476-8070.2010.01632.x.

[9] D. Henriksen, C. Richardson and R. Mehta, Design thinking: A creative approach to educational problems of practice, Thinking Skills Creativity, vol. 26, pp. 140-153, 2017. DOI: https://doi.org/10.1016/j.tsc.2017.10.001.

[10] J. Salpeter. 21st Century Skills: Will Our Students be Prepared? Technology \& Learning. www.techlearning.com/ article/13832 (accessed Dec. 22, 2009).

[11] B. Wylant, Design thinking and the experience of innovation, Des. Issues, vol. 24, no. 2, pp. 3-14, 2008.

DOI: https://doi.org/10.1162/desi.2008.24.2.3.

[12] J.P. Gee, G. Hull and C. Lankshear, The New Work Order. Sydney, NSW: Allen and Unwin, 1996.

[13] X. Yao, Preliminary research on integrating design thinking into high school art teaching, Art Educ. Res., no. 5, pp. 122-123, 2017. DOI: https://doi.org/10.3969/j.issn.16749286.2017.05.083.

[14] TEDx Talks. How Humility, Courage, and Empathy Help Navigate the Creative Process: Seung Chan Lim at TEDxPSU. (Apr. 28, 2014). [Online Video]. Available:

https://www.youtube.com/watch?v=Wm0GKnd3Jv A.

[15] L. Aflatoony, R. Wakkary and C. Neustaedter, Becoming a design thinker: Assessing the learning process of students in a secondary level design thinking course, Int. J. Art Des. Educ., vol. 37, no. 3, pp. 438-453, 2017. DOI: https://doi.org/10.1111/jade.12139.

[16] A. Scheer, C. Noweski and C. Meinel, Transforming constructivist learning into action: Design thinking in education, Des. Technol. Educ.: Int. J., vol. 17, no. 3, pp. 8-19, 2012.

[17] F. Habbal, Embedding design thinking in a multidisciplinary engineering curriculum at Harvard University, in Creating Innovation Leaders 
Understanding Innovation. New York: Springer, 2016, pp. 149-162.

[18] A.D. Watson, Design thinking for life, Art Educ., vol. 63, no. 3, pp. 12-18, 2015. DOI: https://doi.org/10.1080/00043125.2015.11519317.
[19] E. W. Eisner, The arts and the creation of mind. New Haven: Yale University Press, 2002. 